\title{
Nutritive Potentials and Utilization of Sardine Head Meal in the Diet of African Cat Fish
}

\author{
Christianah Oludayo Olaniyi ${ }^{1}$, Deborah Airebamen ${ }^{2}$ \\ Department of Animal Production and Health, Ladoke Akintola University of Techmology, Ogbomoso Oyo State. Nigeria
}

\begin{abstract}
Sardine is one of the families of fish commonly found in Nigeria waters. It is highly acceptable, and cheaper. In spite of these values, sardine head are majorly regarded as waste by consumers; therefore this study was conducted to investigate the possibility of using sardine head meal as a protein source in African catfish diet. 180 African catfish fingerlings (+ -22.77) were separated into four groups; 15fingerlings were stocked per tank and replicated three times. The fingerlings were fed with five iso-nitrogenous diets (40\% crude protein) formulated with four different inclusions of sardine head meal: 0\% (control diets),5\% (diets 2), 10\% (diet 3), 15\% (diet 4) for the period of 8weeks. At the end of the feeding period, the mean weight gain (MWG), percentage weight gain (PMWG), specific growth rate $(S G R)$ increased significantly $(p<0.05)$ as the inclusion level of sardine head meal increased up to 10\%. Feed acceptability was very high in all the treatments. However, treatment 2 (5\% SHM) had the least mean feed intake (77.10g). The FCR were also significantly different $(p<0.05)$ and the least FCR (1.37) was obtained for treatment 2 . In the same vein, highest protein efficiency ratio (1.83) was recorded for treatments 2 and 3, indicating that fish fed 5\% was able to utilize the protein efficiently compared to other treatments. It could therefore be concluded that inclusion of 5\% sardine head meal in the diet of African cat fish would improve growth and improve protein utilization in African cat fish.
\end{abstract}

Keywords: protein efficiency ratio, growth, inclusion level, sardine head meal

\section{Introduction}

Globally, aquaculture is the fast growing food producing sector. The supply was growing at a rate of $32.4 \%$ with per capital supply increasing from $0.7 \mathrm{~kg}$ in 1970 to $7 \mathrm{~kg}$ in 2004 representing an average annual growth rate of $7.1 \%$ (FAO, 2006).

In Africa, it is a different case particularly in Nigeria where the capture fisheries play the leading role and aquaculture is minors in fish production, despite its natural potential. However, in this region, Nigeria is the leading country producing Catfish, tilapia and other freshwater fishes, with the production of 44,000 tonnes. (FAO, 2006).

Among the culturable fish in Nigeria, African catfish is the most sought after fish species. It is highly demand by the fish farmers and consumers due to its high commercial value, as it is tasty, hardy and tolerate poor water quality conditions and also capable of reproducing in captivity (Ayinla et al, 1994)

Inspite of all the abilities recorded, the major problem facing catfish production and aquaculture at large is the issue of sudden increase in cost of feed due to growing scarcity and supply with escalating cost of quality fishmeal.

Fishmeal is the major animal protein required in fish feed. Therefore, replacing fishmeal with cost effective dietary protein source of equal or that compare favorably in quality is a priority research.

Various plant sources for partial and complete replacement of fishmeal has been investigated by a number of researchers (Olvera - Novoa et al, 1990;; Lee et al., 2006 and Olaniyi et al., 2013). Although, plant proteins are cost effective but deficient in aminoacids and minerals. However, the presence of anti nutrients has limited its use in fish feed (NRC, 1993 Vielina et al, 2003).
All these pressure has necessitated the need to evaluate cheaper ingredients with little or no relevance in human nutrition which could be used in fish feed formulation.

Wastes are generated by Agricultural Industrial and municipal segments of the population. The amount of waste generated by these sectors have resulted to severe environmental and financial strain on both the populace and government. However, the ever increasing problem and cost of waste disposal has provoked interest in the possibility of recycling wastes for the benefits of man. One of the prominent outlets for use of waste has been in feeding animals thereby reducing the cost of feed (Gill, 2000).

Agricultural wastes consist of both plant and animal wastes. Plant wastes are found to contain poor protein quality which has actually reduced its use in fish feed.

Most animal wastes had been investigated in feed formulation of African catfish such as use of peri wrinkles flesh (Akegbejo - Samsons, 1999); Replacing fishmeal with Rumen contents (Olaniyi et al., 2008) were found to compare favourably with fishmeal with little or no adverse effect on the health of the fish. In recent decade, shell fish production has gained ground and expanding with larger quantities of crustacean and mollusc waste being produced, which may represent more than $80 \%$ of the landing (Martin, 1994). These shell fish waste consist mainly of shell, viscera, heads, and adhere meat, and they can be used in the production of fish meal for animal consumption (Martin, 1994). Sardine fish is one of the commonest and popular fish consumed in Africa due to its affordable price. Sardine is highly nutritious and very rich in quality protein with a good profile of essential amino acids (FAO, 2000) . However, sardine head is bony and the acceptability both commercially is very low Most consumer do prefer beheading the sardine right away from the store where it was purchased meaning that sardine head is of less value. Therefore, sardine head had added to the level of 


\section{International Journal of Science and Research (IJSR) \\ ISSN (Online): 2319-7064}

Index Copernicus Value (2013): 6.14 | Impact Factor (2014): 5.611

environmental waste. Hence, increasing problem and cost of waste disposal has highly necessitated the need for recycling sardine head wastes as feed for the fish. This study therefore evaluates the potential use of sardine head in the nutrition of African catfish.

\section{Materials and Methods}

\section{Experimental site}

The experiment was carried out at the fishery unit, Ladoke Akintola University Teaching and Research Farm, Department of Animal Production and Health for the period of eight weeks.

Experimental Procedure

The fingerlings used were purchased at a reputable farm in Ogbomoso, Oyo state. They were acclimatized for three weeks (3) in the farm before exposed to treatments.

One hundred and eighty African catfish fingerlings were allotted to four groups, stocked in circular plastic tanks of 50liters size, at the rate of fifteen fingerlings per tank and the treatments were replicated three times. The water used was sourced from the university farms, exposed for a minimum of three days to allow aeration. The fish were acclimatized for two weeks before the feeding commences.

Processing of Sardine Head

Sardine heads were obtained from a sardine fish seller in one of the popular market in Ogbomoso metropolis. They were oven dried in a Gallenkamp oven at $60^{\circ}$ to obtain a constant weight for easy grinding. It was grounded using manual grinder to obtain right particle size for pelleted feed.

\section{Experimental Diets}

Feed ingredients such as maize, rice bran, groundnut cake, fishmeal blood meal, vegetable oil, oyster shell, bone meal, salt, premix, lysine were purchased from a reputable feed mill in Ogbomoso. Four experimental diets were formulated such that diet 1 contained $0 \%$ of Sardine head meal and serve as control and diet 2, 3 and 4 contained 5\%,10\% and $15 \%$ sardine head meal respectively.

The ingredients were weighed according to their calculated weight, mixed thoroughly and then pelletized to avoid dustiness and for proper acceptance by fingerlings. The pellets were sun dried for two days and stored in an air tight container to prevent deterioration.

Table 1: Gross Composition of Experimental Diets $(\mathrm{g} / 100 \mathrm{~g})$

\begin{tabular}{|c|c|c|c|c|}
\hline Ingredients & D1 (control) & D2 (5\%) & D3 (10\%) & D4 (15\%) \\
\hline YM & 10.61 & 9.05 & 7.47 & 5.93 \\
\hline RH & 3.54 & 3.02 & 2.49 & 1.98 \\
\hline SB & 53.54 & 51.59 & 49.66 & 47.69 \\
\hline FM & 26.77 & 25.79 & 24.83 & 23.85 \\
\hline SHM & - & 5.00 & 10.00 & 15.00 \\
\hline BM & 2.00 & 2.00 & 2.00 & 2.00 \\
\hline OS & 1.50 & 1.50 & 1.50 & 1.50 \\
\hline PREMIX & 2.00 & 2.00 & 2.00 & 2.00 \\
\hline SALT & 0.05 & 0.05 & 0.05 & 0.05 \\
\hline
\end{tabular}

$\mathrm{YM}$ - yellow maize, $\mathrm{RH}$ - rice bran, $\mathrm{SB}$ - soybean, FM fishmeal, SHM- sardine head, BM - bone meal, OS - oyster shell.

\section{Feeding and Management of the Fingerlings}

The fingerlings were fed 3\% of their total body weight daily. Feeding was done twice daily at $0900 \mathrm{hrs}$ and $1500 \mathrm{hrs}$ and the feeding regime was adjusted with respect to body weight every two weeks

\section{Chemical Analysis}

The proximate composition of the test ingredients (Sardine head) and fish samples were determined on dry matter basis using the method of A.O.A.C (1990). The carcass analysis was done at the beginning and also at the end of experiment for all the treatments.

\section{Data Collection}

The parameters measured were Weight Gain, Average Daily Weight Gain and Feed intake. Each of these parameters was measured every two weeks. Performance characteristics were evaluated according to the method of Olvera- Nova et al, (1990) as follows:

Mean Weight Gain (MWG) = Final mean weight (g) - Initial mean weight $(\mathrm{g})$;

Average Daily Weight Gain (ADWG) = Mean weight gain (g) / length of feeding trial (days);

Percentage Weight Gain $(\mathrm{PWG})=$ Mean weight gain $(\mathrm{g}) /$ Initial mean weight; $\mathrm{x} 100$

Specific growth rate $\left(\mathrm{SGR} \% /\right.$ day) $=100\left[\left(\log _{\mathrm{e}} \mathrm{W}_{2}-\right.\right.$ $\left.\log _{\mathrm{e}} \mathrm{W}_{1}\right) / \mathrm{N}_{\mathrm{O}}$ of days

Feed conversion ratio $(\mathrm{FCR})=$ total feed fed $(\mathrm{g}) /$ net weight gain $(\mathrm{g})$;

Protein Intake $(\mathrm{PI})=$ total feed consumed X \% Crude protein in feed

Feed intake $(\mathrm{FI})=$ This is the amount of feed throughout the period of the experiment ;

Protein Gain $(\mathrm{PG})=$ mean protein intake $(\mathrm{g}) /$ length of feeding trial (days);

Protein Efficiency Ratio (PER) = Net weight gain $(\mathrm{g}) /$ Amount of protein fed (g) while

Protein productive Value $(\mathrm{PPV})=$ protein gain in fish $(\mathrm{g}) /$ Protein in food $(\mathrm{g}) \times 100$.

\section{Statistical Analysis}

The results were subjected to One Way Analysis of Variance (ANOVA) using completely randomized design (CRD), SAS (2000). Means were separated by Duncan's Multiple Range Test using the same computer package.

\section{Results}

Table 2: Proximate Composition of Sardine Head Meal

\begin{tabular}{|c|c|c|c|c|}
\hline Parameters & $\begin{array}{c}\text { Crude } \\
\text { protein \% }\end{array}$ & $\begin{array}{c}\text { Ether } \\
\text { extract \% }\end{array}$ & Ash \% & Moisture \% \\
\hline & 31.50 & 29.76 & 14.23 & 16.69 \\
\hline
\end{tabular}




\section{International Journal of Science and Research (IJSR) \\ ISSN (Online): 2319-7064 \\ Index Copernicus Value (2013): 6.14 | Impact Factor (2014): 5.611}

Table 3: Growth Performance of African cat fish fingerlings fed Sardine head meal.

\begin{tabular}{|c|c|c|c|c|c|}
\hline Parameters & T1 (control) & T2(5\%) & T3(10\%) & T4(15\%) & SEM \\
\hline MWG (g) & $49.25^{\mathrm{d}}$ & $56.38^{\mathrm{a}}$ & $54.97^{\mathrm{b}}$ & $52.66^{\mathrm{c}}$ & 0.20 \\
\hline PWG (\%) & $215.35^{\mathrm{d}}$ & $338.74^{\mathrm{c}}$ & $379.85^{\mathrm{a}}$ & $374.80^{\mathrm{b}}$ & 1.20 \\
\hline SGR (g/day) & $0.89^{\mathrm{c}}$ & $0.93^{\mathrm{b}}$ & $0.98^{\mathrm{a}}$ & $0.93^{\mathrm{b}}$ & 0.05 \\
\hline FCR & $1.60^{\mathrm{a}}$ & $1.37^{\mathrm{c}}$ & $1.52^{\mathrm{b}}$ & $1.62^{\mathrm{a}}$ & 0.02 \\
\hline MFI (g) & $78.77^{\mathrm{c}}$ & $77.13^{\mathrm{d}}$ & $83.53^{\mathrm{b}}$ & $85.23^{\mathrm{a}}$ & 1.02 \\
\hline PI (\%) & $31.51^{\mathrm{c}}$ & $30.85^{\mathrm{c}}$ & $33.41^{\mathrm{b}}$ & $34.09^{\mathrm{a}}$ & 0.15 \\
\hline PER & $1.56^{\mathrm{c}}$ & $1.83^{\mathrm{a}}$ & $1.65^{\mathrm{b}}$ & $1.54^{\mathrm{c}}$ & 0.02 \\
\hline
\end{tabular}

Parameters on each row with different superscripts are significantly different at $\mathrm{P}<0.05$. T-treatment, $\mathrm{MWG}-$ mean weight gain, $\mathrm{PWG}$ - percentage weight gain, SGR - specific growth rate, FCR -feed conversion ration, MFI - mean feed intake, PI -protein intake, PER -protein efficiency ratio. SEM -standard error of mean

Table 4: Proximate Carcass Composition Clarias Gariepinus Before and After The Feeding Trial.

\begin{tabular}{|l|l|l|l|l|l|l|}
\hline Parameters & $\begin{array}{l}\text { Initial } \\
\text { carcass }\end{array}$ & $\begin{array}{l}\text { T1 } \\
(\mathbf{0} \%)\end{array}$ & $\begin{array}{l}\text { T2 } \\
\mathbf{5} \%\end{array}$ & $\begin{array}{l}\text { T3 } \\
\mathbf{1 0} \%\end{array}$ & $\begin{array}{l}\text { T4 } \\
\mathbf{1 5} \%\end{array}$ & SEM \\
\hline CP & $58.98^{\circ}$ & $62.56^{\mathrm{a}}$ & $59.76^{ }$ & $59.61^{\mathrm{d}}$ & $1.25^{\mathrm{b}}$ & 0.02 \\
E.E & $14.48^{\mathrm{a}}$ & $11.53^{\mathrm{c}}$ & $11.41^{\mathrm{d}}$ & $10.64^{\mathrm{e}}$ & $11.69^{\mathrm{b}}$ & 0.03 \\
ASH & $11.39^{\mathrm{a}}$ & $10.27^{\mathrm{c}}$ & $9.75^{\mathrm{d}}$ & $10.43^{\mathrm{b}}$ & $10.19^{\circ}$ & 0.03 \\
\hline MO & $9.60^{\mathrm{d}}$ & $9.33^{\circ}$ & $11.49^{\mathrm{a}}$ & $9.70^{\mathrm{c}}$ & $9.81^{\mathrm{b}}$ & 0.03 \\
\hline
\end{tabular}

$\mathrm{SEM}=$ Standard Error of Mean, MO = Moisture, SH: Sardine head meal $=$ Initial carcass of the fish before feeding trial, $\mathrm{CP}=$ crude protein, $\mathrm{T} 1=$ Treatment $1, \mathrm{~T} 2=$ Treatment $2, \mathrm{~T} 3=$ Treatment 3, T4 = Treatment 4, E.E $=$ Ether extract.

Table 5: Water parameters in experimental tanks for the period of the experiment.

\begin{tabular}{|c|c|}
\hline Parameters & Range \\
\hline $\mathrm{pH}$ & $8.5-9.3$ \\
\hline Temperature ${ }^{0} \mathrm{C}$ & $25.3-32.9$ \\
\hline Total ammonia $\left(\mathrm{mg} / \mathrm{NH}_{3}{ }^{+}\right)$ & $0.19-4.22$ \\
\hline Total alkalinity $\left(\mathrm{mg} / \mathrm{CaCO}_{3}\right)$ & $27.9-4.69$ \\
\hline Dissolved oxygen $(\mathrm{mg} / \mathrm{l})$ & $8.64-12.5$ \\
\hline
\end{tabular}

The proximate analysis of sardine head meal in Table 2 was reported to contain $31.50 \%$ Crude protein, $29.76 \%$ Crude fat and $14.23 \%$ Ash.

Table 5 revealed the Water quality parameters, the dissolved oxygen ranged from $8.64-12.5 \mathrm{mg} / 1$ and the water temperature was between 25.3 and $32.9{ }^{\circ} \mathrm{C}$

Table 3 showed the parameter observed and recorded for the growth performance and nutrient utilization of Clarias gariepinus fingerlings fed varying inclusion levels $(0 \%, 5 \%$, $10 \%$ and $15 \%$ ) of sardine head meal. The final weight gain were significantly different $(\mathrm{p}<0.05)$ in all the treatments. The highest value of $76.14 \mathrm{~g}$ was recorded in treatment 2 while the lowest value of $66.02 \mathrm{~g}$ was recorded in treatment 4. The mean weight gain (MWG) were also significantly different $(\mathrm{p}<0.05)$. The highest value of MWG $56.37 \mathrm{~g}$ was recorded in treatment 2 while the lowest value $48.52 \mathrm{~g}$ was recorded at treatment 4 . The specific growth rate (SGR) were not significantly different $((p>0.05)$ in treatment 1 and treatment 3 while treatment 2 and 4 were significantly different $(\mathrm{p}<0.05)$. The highest value of SGR $(1.03 \%)$ was recorded in treatment 4 and the lowest value $(0.88 \%)$ was found with treatments 1 and 3. Mean feed intake (MFI) showed that there were significant $(\mathrm{p}<0.05)$ difference in all the treatments. The highest value (83.08) was observed in treatment 3 while the lowest value (68.16) observed was in treatment 4 . Feed conversion ratio (FCR) was significantly $(p<0.05)$ different in all the treatment. The highest value of FCR (1.67) recorded was in treatment 3 while the lowest value (1.37) was recorded in treatment 2 which is the best feed conversion ratio .Protein intake (PI) in all treatment were significantly $(\mathrm{p}<0.05)$ different. The highest PI $(33.23)$ recorded was found in treatment 3 while the lowest value (27.26) obtained in treatment 4. Protein efficiency ratio $(P E R)$ in all treatment were significantly $((\mathrm{p}<0.05)$ different. The highest PER (1.83) was recorded in treatment 2 while the lowest value(1.48) was obtained in treatment 3.

The result of the carcass composition of Clarias gariepinus before and after the experiment is as shown in table 4 . The Crude protein $(\mathrm{CP})$ were significantly different $(\mathrm{p}<0.05)$ with the highest recorded value of $62.56 \%$ in treatment 1 and the lowest value of $58.98 \%$ by the initial carcass followed by $59.61 \%$ in treatment 3 . The crude fibre were also significantly different $(\mathrm{p}<0.05)$ in all the inclusion levels, highest value $(1.05 \%)$ was obtained in treatment 2 while the lowest value of $0.66 \%$ was indicated by the initial carcass followed by $0.75 \%$ in treatment 1 and $0.90 \%$ in treatment 3. Ether extract indicated that there were significant $(p<0.05)$ differences in all the inclusion levels. The highest value of EE $14.48 \%$ was recorded by the initial carcass followed by $11.69 \%$ in treatment 4 while the lowest value was recorded as $(10.64 \%)$ in treatment 3 . Ash indicated that there were no significant different $(p>0.05)$ in treatment 1 and treatment 4 while in initial, treatment 2 , and treatment 3 shows that there were significant $(\mathrm{p}<0.05)$ different. The highest value recorded was $11.39 \%$ (initial level) followed by $10.43 \%$ in treatment 3 , while the lowest value was $9.75 \%$ in treatment 2 . Moisture showed that there was significant different $(\mathrm{p}<0.05)$ in all treatment. The highest value was recorded in treatment $2(11.49 \%)$ while the lowest value was recorded as $9.33 \%$ in treatment 1 followed by $(9.70 \%)$ in treatment 3

\section{Discussion}

The potential of a feedstuff such as sardine head waste meal in fish diets can be evaluated mainly on the basis of its proximate composition, particularly the crude protein content. The chemical composition of sardine head meal in this research revealed that the CP content was $31.50 \%$. This value was lower than the value $(35-50 \%)$ reported by (Adebayo and Quadri, 2005). The difference in the value might be attributed to sources or area of collection of sardine in the wild and varieties of species collected from the market for the experiment .Mean while, the nutritional quality of fish waste (sardine head meal) would be determined by the growth parameters such as weight gain, protein efficiency ratio, specific growth rate and feed conversion ratio of the fish.

This study showed that fish survival rate decreased with increasing dietary fish waste meal although there was no fish

\section{Volume 4 Issue 12, December 2015}




\section{International Journal of Science and Research (IJSR) \\ ISSN (Online): 2319-7064}

Index Copernicus Value (2013): 6.14 | Impact Factor (2014): 5.611

diseases infestation detected during the experimental period. Reduced growth rate observed generally in fishes of all the treatments may also be in connection with the high percentage of crude fat in the sardine head meal which may likely dissociate in water and impairing the gills ability to absorb enough dissolved oxygen from the water (during feeding period) for normal growth and this may also affect the feed intake (Viveen et al., 1985). However, water quality parameters were within the recommended level for Clarias gariepinus (Boyd, 1981)

Only $5 \%$ of the dietary fishmeal can be replaced by sardine by-product protein derived from local fisheries processing. This indicates that protein from fisheries by-product could not effectively replace fishmeal protein in diets of African catfish possibly because of lower amino acid imbalance and poor utilization of nutrients.

In this study, weight gain, Feed conversion ratio, and Protein efficiency ratio of fish improved as dietary SHM inclusions increased up to $5 \%$. The performance at this level suggests that nutrients rich in amino acids are made available for fish to utilize up to $5 \%$ since both are from fish source. This finding is similar to the reports of (Sotolu and Faturoti, 2008; Collazos and Guio 2005.) that biological fish waste supplementation to diet improved egg weight, weight gain, egg shell thickness and yolk percentage in laying Japanese quails. Low feed intake experienced by the fish generally among the treatments may be due to the presence and quantity of exoskeleton ( chitin)and ash in the meal (Bhuiyan, 1989) that impede nutrient utilization. Least FCR observed in treatment 2 ( $5 \%$ inclusion of SHM) is an indication that the feed to flesh conversion rate of the fish fed 5\% inclusion of SHM was very high compare to others despite its low level of feed intake.

The proximate composition of fish sample showed that there was appreceiable increase in the protein and lipid contents of the experimental fish at the end of the study. However, fish fed whole fish meal ( control - diet 1) gained much more protein than others meaning that the quality of protein in fish meal is very high compared with that of sardine head meal. Inspite of this, higher weight gain, SGR, PER and lower FCR recorded for treatment 2 suggested that 5\% SHM provided fish with more nutrients.

\section{Conclusion}

From the results obtained, diet 2 (5\% sardine head meal) had the best performance in term of MWG,FCR, PER, therefore it can be concluded that inclusion of sardine head meal in the diet of African cat fish up to $5 \%$ will enhance better growth without any adverse effect on the fish and likewise maximize profit.

\section{Recommendation}

In order to enhance better and optimum utilization, it is suggested that further processing of sardine head meal need to be carried out.

\section{References}

[1] Adebayo, O.T. and Quadri, I.C. 2005.Dietary protein level and feeding rate for Hybrid Clarid Catfish, Clarias gariepinus $\mathrm{x}$ Heterobanchus bidorsallis in homestead tanks. Journal of Applied Aquaculture 17 (1):97- 106.

[2] Akegbejo - Samsons, Y. (1999). Growth response and nutrient digestibility by Clarias gariepinus fed varying levels of dietary peri wrinkles flesh as replacement for fishmeal in low cost diets. Applied Tropical Agriculture 4: $37-41$

[3] A.O.A.C (1990). Association of Official Analytical Chemists. Official Methods of Analysis (15 ${ }^{\text {th }}$ ed.) A.O.A.C Inc. Arington, Viirginia, USA, 1094p.

[4] Ayinla, O.A, Kayode, O. Idoni boye - obu, O.E; Oresegun A; Adibu, V.E (1994). Use of tadpole meal as substitute for fishmeal in the diet of $\mathrm{H}$. bidorsal J. Aqua. Trop. 9(1): 25- 33 .

[5] Boyd, C.E. (1981): Water Quality in Warm Water Fishes Prods. Auburn university agriculture.Experiment Station, pp. 359.

[6] Bhuiyan, A.K.M (1989).Survey of potential fish feed ingredients of Bangladesh on the basis of their availability and biochemical composition of fisheries research institute. Fresh water station Mymensingh, Bangladesh, Report 1:70

[7] Collazos, H. and C. Guio 2005. The effects of dietary biological fish silage on performance and egg quality of laying Japanese quails (Coturnix coturnix japonica).

[8] FAO (Food and Agriculture Organization), (2000). State of World Fisheries and Aquaculture, FAO Report, Rome.

[9] FAO (2006) Food and Agriculture Organisation of the United nation Aquaculture, FAP report.

[10] Gill, T.A., (2000). Waste from processing aquatic animals and animal products: implications on aquatic animal pathogen transfer. FAO (Food and Agriculture Organization) Fisheries Circular, 956: 26.)

[11]Lee K.J., Rinchard J., Debrowski K; Babiak I., Ottobre J.S and Christensen J.E (2006). Long term effects of dietary cottonseed meal on growth and reproductive performance of rainbow trout: Three - year study. Animal feed science Technology 126:93-106

[12] Martin, A.M. (Ed.), (1994). Fisheries Processing, Chapman and Hall, London

[13] National Research Council (NRC) (1993). Nutrient requirements of fish. National Academy Press, Washington, DC 124.

[14] Olaniyi, C.O., Sodeinde, F.G and Akande, T.O (2008). Growth performance and nutrient utilization of rumen content in the nutrition of African Catfish (Clarias gariepinus) Burchell, 1822. Proceedings of $13^{\text {th }}$ Annual Conference of Anima Science Association of Nigeria (ASAN) ABU, Zaria, $15^{\text {th }}-19^{\text {th }}$ September, pp $474-$ 478.

[15] Olaniyi, C.O. and Ajani, N.O . and Adetomi, M.N. (2013). Growth performance and nutrient utilization of Clarias gariepinus fed Moringa oleifera leaf meal. Journal of Natural Sciences 3(7):1 - 13.

[16] Olivera-Nova, M.A, Campus, G., Sabido, G.M. and Martinez- Palacois (1990). The use of alfalfa leaf protein concentrates as a protein source in the diets for 


\section{International Journal of Science and Research (IJSR) \\ ISSN (Online): 2319-7064}

Index Copernicus Value (2013): 6.14 | Impact Factor (2014): 5.611

Tilapia (Oreochromis mossambicus) Aquaculture, 90, $201-302$.

[17] Sotolu, A.O. and E.O. Faturoti, 2008. Digestibility and Nutritional Values of Differently processed Leucaena leucocephala (Lam De Wit) Seed Meals in the Diet of African Catfish (Clarias gariepinus). Middle-East J. Sci. Res., 3(4): 190-199.

[18] Vielina J, Koskela J., Ruohomen K., Jokinem I. and Ketumen J. (2003). Optimal diet composition for European whitefish (Coregonus lavaretus); Carbohydrate stress and immune parameter responses. Aquaculture 22,5; 3-16

[19] Viveen, W.J.A.R., and Rich, L.J (1985). Dissolved Oxygen required for Catfish Rearing, Practical Manual for Culturable catfish. Department of Fish culture and Fisheries, Page 2-8. 